\title{
Pengaruh Kualitas Produk dan Desain Terhadap Keputusan Pembelian Motor Yamaha Vixion
}

\author{
Siti Aisyah, ${ }^{1}$ Agustiawan Agustiawan, ${ }^{2,}$ Nurwanita Nurwanita², Fatma Fatma \\ ${ }^{1}$ Jurusaan Ekonomi Syariah, Fakultas Ekonomi dan Bisnis Islam, IAIN Palu \\ ${ }^{2}$ Jurusaan Ekonomi Syariah, Fakultas Ekonomi dan Bisnis Islam, IAIN Palu \\ ${ }^{3}$ Jurusaan Ekonomi Syariah, Fakultas Ekonomi dan Bisnis Islam, IAIN Palu
}

\section{ABSTRAK}

Tujuan penelitian ini adalah untuk mengetahuai kualitas produk dan desain berpengaruh secara parsial dan secara serempak terhadap keputusan pembelian motor yamaha vixion pada organisasi vixion di kota Palu. Lokasi pada penelitian ini di wilaya kota palu provinsi Sulawesi Tengah. Populasi dalam penelitian ini adalah seluruh anggota organisasi vixion di Kota Palu yang berjumlah 8 organisasi yaitu Vixion Young Riders Community, Rider Vixion Independen, Yamaha Vixion Club Indonesia, Vixion Jari-Jari Palu Vixion Ruji Squad Palu Celebes Vixion Club Dan Vixion Independen Club yang jumlah keseluruhan anggota 282 anggota. Teknik pengambilan sampel yang digunakan adalah teknik sample random sampling sebanyak 74 orang, dengan menggunakan rumus slovin untuk menentukan jumlah sampel. Teknik pengumpulan data adalah melalui teknik observasi, kuesioner, dan wawancara, SPSS 21 For Windows. Dan teknik analisa yang digunakan adalah analisis regresi linear berganda. Hasil penelitian ini menunjukkan bahwa variabel yang terdiri dari kualitas produk, dan desain secara serempak berpengaruh terhadap keputusan pembelian Motor Yamaha Vixion Studi Pada Organisasi Vixion di Kota Palu . Sedangkan, secara parsial desain berpengaruh secara signifikan terhadap keputusan pembelian Motor Yamaha Vixion Studi Pada Organisasi Yamaha Vixion di Kota Palu, sedangkan kualitas produk berpengaruh tetapi tidak signifikan. Nilai koefisien determinasi (R2) menunjukkan bahwa variabel independen yang diteliti mampu menjelaskan 11,3\% pengaruhnya terhadap variabel dependen (Keputusan Pembelian Motor Yamaha Vixion Studi Pada Organisasi Yamaha Vixion di Kota Palu, sedangkan sisanya $88,7 \%$ dijelaskan oleh variabel independen yang lain yang tidak termasuk dalam penelitian ini.
INFORMASI

ARTIKEL

Katakunci:

Kualitas produk, desain produk, keputusan pembelian 


\section{Pendahuluan}

Salah satu alat transportasi yang banyak digunakan oleh masyarakat Indonesia adalah alat transpotasi roda dua yaitu sepeda motor. Permintaan masyarakat terhadap sepeda motor terus meningkat, hal ini memberikan peluang para produsen sepeda motor untuk melakukan inovasi dari produk yang dihasilkannya.

Terdapat beberapa hal yang pertama yang harus diperhatikan oleh perusahaan dalam memasarkan produknya adalah mengenai atribut produk yang merupakan segala sesuatu yang melekat dan menyertai produk tersebut, seperti merek, desain, warna, kualitas, fitur, dan sebagainya. Munculnya produk dapat mempengaruhi pilihan konsumen dengan cara yang berbeda-beda. Desain yang baik tidak hanya mempunyai andil dalam menampilkan produk tetapi juga dalam manfaatnya. ${ }^{1}$

Selain Desain dari produk, hal yang tidak kalah penting yang harus diperhatikan oleh seorang produsen dalam melakukan produksi suatu barang adalah kualitas dari produk itu sendiri. Menurut Kotler dan Amstrong kualitas produk merupakan salah satu sarana positioning utama pasar. Kualitas produk mempunyai dampak langsung pada kinerja produk atau jasa, oleh karena itu kualitas berhubungan erat dengan nilai pelanggan. Dalam artian

1Agustin Dwi Carrisa." Pengaruh Desain Produk dan Promosi Penjualan Terhadap Keputusan Pembelian Pada Sepeda Motor Yamaha Vega ",Jurnal (Surabaya: Universitas Negeri Surabaya. 2015 ), http://jurnalmahasiswa. Unesa.ac.id (diakses 10 Januari 2019) sempit kualitas bisa didefinisikan sebagai bebas dari kerusakan. ${ }^{2}$

Setelah berhasil memproduksi barang dan jasa dengan desain yang baik dan berkulitas tinggi maka, seorang produsen harus memperhatikan beberapa hal terkait pemasaran produk atau jasa tersebut yaitu, perilaku pembelian dari konsumen. Perilaku pembelian sesorang dapat dikatakan suatu yang unik, karena preferensi dan sikap terhadap objek setiap orang berbeda. Selain itu konsumen berasal dari segmen, sehingga apa yang diinginkan dan dibutuhkan juga berbeda. Masih terdapat banyak faktor yang berpengaruh terhadap keputusan pembelian.

Oleh karena itu produsen perlu memahami perilaku konsumen terhadap produk atau merk yang ada di pasar, selanjutnya perlu dilakukan berbagai cara untuk membuat konsumen tertarik terhadap produk yang di hasilkan.

$$
\text { Assael dalam Asih }
$$

mengembangkan model perilaku konsumen dengan menerapkan tiga faktor yang berpengaruh terhadap perilaku konsumen. ${ }^{3}$ Faktor yang pertama yang berpengaruh pada konsumen adalah stimuli. Stimuli menunjukan penerimaan informasi oleh konsumen dan pemrosesan informasi

2Philip Kotler dan Gary Amstrong, Prinsip-Prinsip Manajemen, (Jakarta : Erlangga : 2006), 272.

3 Nurdin, N. (2016). The Roles of Information Technology in Islamic Bank Knowledge Management: A study of Two Syariah Banks in Palu. Hunafa: Jurnal Studia Islamika, 13(2),

181-217. https://doi.org/https://doi.org/10.24239/jsi.v1 3i2.444.181-217 
saat konsumen mengevaluasi informasi dari periklanan, teman atau dari pengalaman sendiri. Pengaruh kedua berasal dari karateristik pribadi konsumen meliputi persepsi, sikap, manfaat serta karakteristik konsumen (demografi, kepribadian, gaya hidup). Pengaruh yang ketiga respon konsumen yaitu hasil akhir dari proses keputusan konsumen dan suatu pertimbangan yang menyeluruh dari semua faktor di atas. ${ }^{4}$

Salah satu perusahaan besar yang bertindak sebagai produsen yang memproduksi sepeda motor yaitu Yamaha yang berasal dari Negara Jepang dan di Indonesia sendiri bernama PT Yamaha Indonesia. Perusahaan ini merupakan perusahaan dengan urutan kedua dalam hal penjualan sepeda motor terbesar di Indonesia. Salah satu dari produk sepeda motor yang dihasilkan oleh perusahaan ini adalah Yamaha Vixion.

Yamaha vixion adalah merek sepeda motor bertipe sport yang diproduksi oleh Yamaha Motor Indonesia. Sepeda motor ini diluncurkan pada tahun 2007. Yamaha Vixion merupakan sepeda motor pertama yang diproduksi oleh Yamaha Motor Company dengan menggunakan teknologi sistem injeksi bahan bakar. Sepeda motor ini bersaing di kelas 150

\footnotetext{
${ }^{4}$ Asih Purwanto " Pengaruh Kualitas Produk, Promosi, dan Desain Terhadap Keputusan Pembelian Kendaraan Bermotor Yamaha Mio" Skripsi (surakarta: Universitas Muhammadiyah Surakarta, 2008), hppt://eprints. ums.ac. id (Diakses, 10 januari 2019)
}

cc untuk mengimbangi kompetitor dari produsen lainnya. ${ }^{5}$

Seperti yang diketahui sekarang bahwasanya penjualan motor khususnya Yamaha Vixion di wilayah Sulawesi Tengah sudah cukup banyak. Penjualan motor Yamaha Vixion di Sulawesi Tengah mencapai 1.000 unit pertahunnya. ${ }^{6} \mathrm{Hal}$ ini dikuatkan dengan maraknya masyarakat dalam menggunakan sepeda motor jenis Yamaha vixion, dan salah satunya organisasi Yamaha Vixion yang berada di wilayah Kota Palu. Pada awal keluaran motor Yamaha Vixion hanya terdapat beberapa organisasi Yamaha Vixion seperti Generasi Vixion Club Indonesia, Yamaha Vixion Club Indonesia, Vixion Young Raiders Community, dengan perkembangan zaman, mulai lah banyak dibuat organisasi motor Yamaha Vixion di kota Palu seperti : Vixion Jari Jari Palu, Vixion Ruji Squad Palu, Celebes Vixion Club, dan Vixion Independent Club. ${ }^{7}$ Berdasarkan latar belakang tersebut peneliti tertarik meneliti seberapa besar pengaruh kualitas produk dan desain terhadap keputusan pembelian Yamaha Vixion di Kota Palu

\section{Kerangka Teori}

\subsection{Kualitas Produk}

Menurut Thamrin Abdullah dan Francis Tantri Kualitas adalah

${ }^{5}$ Wikipedia, Pengertian Yamaha Vixion, http://id.m.wikipedia.org/wiki/yamaha_vxion, (diakses 10 Januari 2018)

'Indra Gunawan, selaku Jendral Marketing, wawancara tanggal 14 Februari 2019 di CV Akai Jaya Central.

7Rio Ferdinand, Ketua Forum Bikers Bersatu Sulawesi Tengah, wawancara tanggal 8 Januari 2019 di Sekret Forum. 
keseluruhan ciri dan karakteristik suatu barang atau jasa yang berpengaruh pada kemampuannya untuk memuaskan kebutuhan yang dinyatakan maupun tersirat. Jelas ini adalah definisi kualitas yang berpusat pada pelanggan. Pelanggan memiliki kebutuhan dan pengharapan tertentu. Kita bisa menyatakan bahwa penjual tertentu berkualitas bila produk dan pelayanannya memenuhi atau melebihi harapan pelanggan. Perusahaan yang dapat memuaskan sebagian besar kebutuhan pelanggan hampir sepanjang waktu adalah perusahaan berkualitas. ${ }^{8}$

Dalam maknanya yang sempit, produk adalah sekumpulan atribut fisik nyata yang terakit dalam sebuah bentuk yang dapat diidentifikasikan. ${ }^{9}$ Menurut Kotler dalam buku perilaku konsumen karya Etta Mamang Sangadji merumuskan bahwa kualitas merupakan suatu kondisi dinamis yang berhubungan dengan produk, jasa, manusia, proses, dan lingkungan yang memenuhi atau melebihi harapan.10 Sedangkan kualitas adalah sejauh mana produk memenuhi spesifikasispesifikasinya. ${ }^{11}$

Sedangkan menurut Kotler dan Amstrong kualitas produk merupakan salah satu sarana positioning utama pasar. Kualitas produk mempunyai

8Thamrin Abdullah dan Francis Tantri, Manajemen Pemasaran, (Jakarta: Rajawali Pers, 2013), 44.

${ }^{9}$ Yohanes Lamarto, Konsultan Manajemen, ( Jakarta, Erlangga, : 1984), 222.

${ }^{10}$ Etta Mamang S dan Sopiah, Perilaku Konsumen, (Yogyakarta : Andi : 2014), 99.

11Rambat Lupiyado dan A. Hamdani, Manajemen Pemasaran Jasa, ( Jakarta, Salemba Empat : 2009), 175. dampak langsung pada kinerja produk atau jasa, oleh karena itu kualitas berhubungan erat dengan nilai pelanggan. Dalam artian sempit kualitas bisa didefinisikan sebagai bebas dari kerusakan. ${ }^{12}$

Dengan kata lain, kualitas produk diukur sejauhmana produk tersebut bisa memuaskan pelangganya. Selain itu, produk dapat pula didefinisikan sebagai persepsi pelanggan yang dijabarkan oleh produsen melalui hasil produksinya. Secara lebih rinci, konsep produk total meliputi barang, kemasan merk, label, pelayanan dan jaminan. ${ }^{13}$

Oleh karena itu memperbaiki kualitas produk ataupun jasa merupakan tantangan yang penting bagi perusahaan dalam bersaing dan merupakan faktor penting yang mendorong pertumbuhan ekonomi di pasar global.

a. Alasan Memproduksi Produk Berkualitas

Produk berkualitass prima memang akan lebih atraktif bagi konsumen bahkan akhirnya dapat meningkatkan volume penjualan. Tetapi lebih dari itu, produk berkualitas mempunyai aspek penting lain, yaitu :

1) Konsumen yang membeli produk berdasarkan mutu, umumnya dia mempunyai loyalitas produk yang besar dibandingkan dengan

12Philip Kotler dan Gary Amstrong, Prinsip-Prinsip Manajemen, ( Jakarta : Erlangga : 2006), 272.

${ }^{13}$ Anggitan Rizana A.R," Analisis Pengaruh Kualitas Produk, Harga,dan Promosi terhadap \loyalitas Pelanggan dengan Minat Beli Ulang Sebagai Variabel Intervening" jurnal (kudus, stain kudus, 2013 ), diakses melalui http://eprints.dinus.ac.id (diakses 14 januari 2019 )

e-ISSN: 2686-6633 
konsumen yang membeli berdasarkan orientasi harga. Konsumen berbasis mutu akan selalu membeli produk tersebut sampai saat produk tersebut membuat dia merasa tidak puas karena adanya produk lain yang lebih bermutu. Tetapi selama produk semula masih selalu melakukan perbaikan mutu (quality improvement) dia akan tetap setia dengan tetap membelinya. Berbeda dengan konsumen berbasis harga, dia akan mencari produk yang harganya lebih murah, apapun mereknya. Jadi konsumen terakhir tersebut tidak mempunyai loyalitas produk.

2) Bersifat kontradiktif dengan cara pikir bisnis tradisional, ternyata bahwa memproduksi barang bermutu, tidak secara otomatis lebih mahal dengan memproduksi produk bermutu rendah. Banyak perusahaan menemukan bahwa memproduksi produk bermutu tidak harus berharga lebih mahal. Menghasilkan produk bermutu tinggi secara simultan meningkatkan produktivitas, antara lain mengurangi penggunaan bahan (reduce materials usage) dan mengurangi biaya.

3) Menjual barang tidak bermutu, kemungkinan akan banyak menerima keluhan dan pengembalian barang dari konsumen. Atau biaya untuk memperbaikinya menjadi sangat besar, selain memperoleh citra tidak baik. Belum lagi, kecelakaan yang diderita konsumen akibat pemakaian produk yang bermutu rendah. Konsumen tersebut mungkin akan menuntut ganti rugi melalui pengadilan. Jadi, berdasarkan ketiga alasan tersebut, memproduksi produk bermutu tinggi lebih banyak akan memberikan keuntungan bagi produsen, bila dibandingkan dengan produsen yang menghasilkan produk bermutu rendah. ${ }^{14}$

b. Dimensi Kualitas Produk

Sifat khas mutu suatu produk yang handal harus mempunyai dimensi, karena harus memberi kepuasan dan nilai manfaat yang besar bagi konsumen dengan melalui berbagai cara. Menurut Sviokla dalam Suyadi, kualitas memiliki delapan dimensi pengukuran yang terdiri atas aspek-aspek sebagai berikut $: 15$

1) Perfomance, kinerja di sini merujuk pada karakter produk inti yang meliputi merek, atribut-atribut yang dapat diukur, dan aspek-aspek kinerja individu. Kinerja produk biasanya didasari oleh preferensi subjektif pelanggan yang pada dasarnya bersifat umum.

2) Feature, yaitu aspek yang berguna untuk menambah fungsi dasar, berkaitan dengan pilihan-pilihan produk dan pengembangannya.

3) Reliability, hal yang berkaitan dengan probabilitas atau kemungkinan suatu barang berhasil menjalankan fungsinya setiap kali digunakan.

4) Conformance, hal ini berkaitan dengan tingkat kesesuaian terhadap spesifikasi yang telah ditetapkan sebelumnya berdasarkan keinginan pelanggan

5) Durability, yaitu suatu refleksi umur ekonomis berupa ukuran daya tahan atau masa pakai barang.

14Suyadi Prawirosentono, Filosofi Baru Tentang Manajemen Mutu Terpadu Total Quality Management Abad 21 Studi Kasus dan Analisis,( Jakarta, Bumi Aksara, : 2002 ), 2-3.

15Ibid, 176. 
6) Serviceability, yaitu karakteristik yang berkaitan dengan kecepatan, kompetensi, kemudahan, dan akurasi dalam memberikan layanan untuk perbaikan barang.

7) Asthetics, merupakan karakterisitik yang bersifat subyektif mengenai nilai estetika yang berkaitan dengan pertimbangan pribadi dan refleksi dari preferensi individual.

8) Perceved quality, konsumen tidak selalu memiliki informasi lengkap mengenai atribut-atribut produk. Namun demikian, biasanya konsumen memiliki informasi tentang produk secara tidak langsung.

Kualitas merupakan faktor yang terdapat dalam suatu produk yang menyebabkan suatu produk tersebut bernilai sesuai dengan maksud untuk apa produk diproduksi. Kualitas ditentukan oleh sekumpulan kegunaan atau fungsinya, termasuk di dalamnya daya tahan, ketergantungan pada produk atau komponen lain (kenyamanan dan wujud luar seperti warna, bentuk, pembungkus dan sebagainya).

c. Kualitas Produk dalam Pandangan Islam

Produk pada al- Qur'an dinyatakan dalam dua istilah, yaitu altayyibat dan al-rizq. Al-tayyibat merujuk pada suatu yang baik, suatu murni dan baik, suatu bersih dan murni, suatu yang baik dan menyeluruh serta makanan yang terbaik. Al-rizq merujuk pada makan yang diberkahi tuhan, pemberian yang menyenangkan dan ketetapan Tuhan. Menurut Islam produk adalah berdaya guna yang menghasilkan material, moral, spiritual bagi konsumen. Suatu yang tidak berdaya guna dilarang dalam islam bukan merupakan produk dalam pengertian Islam. Barang dalam ekonomi konvensional adalah barang yang dapat dipertukarkan. Tetapi dalam Islam barang yang dipertukarkan dan berdaya guna secara moral. ${ }^{16}$

\subsection{Perilaku Konsumen}

Sebelum kegiatan pemasaran, yang dilakukan manajer pemasaran adalah harus terlebih dahulu mempelajari perilaku konsumen agar dapat melakukan strategi yang tepat. Menurut Kotler dan Keller:

"Perilaku konsumen adalah studi tentang bagaimana tentang individu, kelompok dan oraganisasi memilih, membeli, menggunakan barang, jasa, ide atau pengalaman untuk memuaskan kebutuhan atau keinginan mereka."17

Perilaku konsumen berpusat kepada pribadi masing-masing setiap orang. Dalam setiap diri manusia tentu memiliki perilaku yang berbeda, begitu juga perilaku dalam pengambilan keputusan. Pemahaman mengenai perilaku konsumen merupakan kunci kesuksesan utama bagi para pemasar. Jadi, dapat diambil individu yang secara langsung melalui suatu proses pengambilan keputusan untuk mendapatkan dan mempergunakan barang atau jasa.

16 Veitzal Rivai Zainal, Muhammad Syafei Antonio, Muliaman Darmansyah Hadad, Islamic Busness Management : Praktik Menejemen Bisnis Yang Sesuai Syariat Islam (Yogyakarta: BPFE, 2014), 380.

17Phlip Kotler dan Kevin Lane Keller, Manajemen Pemasaran, (Cet. XIII; Jakarta: Erlangga, 2009), 166. 
Terdapat tiga alasan mengapa studi perilaku konsumen sangat penting. Pertama, pencapaian tujuan bisnis dilakukan melalui penciptaan kepuasan pelanggan, dimana pelanggan merupakan fokus setiap bisnis. Kedua, studi perilaku konsumen dibutuhkan dalam mengimplementasikan orientasi pelanggan. Untuk itu dibutuhkan pengembangan costumer culture, yaitu budaya organisasi yang mengintegrasikan kepuasan pelanggan ke dalam visi dan misi perusahaan. Ketiga, setiap orang adalah konsumen, oleh sebab itu perlu mempelajari cara menjadi konsumen yang bijak agar dapat membuat keputusan yang optimal. 18

Dasar filosofis tersebut melatarbelakangi analisis mengenai perilaku konsumen dalam teori ekonomi konvensional. Beberapa prinsip dasar dalam analisis perilaku konsumen adalah :

1) Kelangkaan dan terbatasnya pendapatan. Adanya kelangkaan dan terbatasnya pendapatan memaksa orang menetukan pilihan. Agar pengeluaran senantiasa berada dianggaran yang sudah ditetapkan, meningkatkan konsumsi barang atau jasa harus disertai dengan pengurangan konsumsi pada barang atau jasa yang lain. ${ }^{19}$

2) Konsumen mampu membandingkan biaya dengan manfaat. Jika dua barang memberi manfaat yang sama,

18Ita Khairunnisa, Pengaruh Bauran Pemasaran Jasa Terhadap Keputusan Mahasiswa dalam Memilih Perguruan Tinggi IAIN Palu, Skripsi Fakultas Ekonomi 2017.

${ }^{19}$ Mustafa Edwin Nasution Pengenalan Eksklusif Ekonomi Islam, (Jakarta : Kencana ,2007), 58. konsumen akan memilih yang biayanya lebih kecil. Di sisi lain, bila memperoleh 2 jenis barang dibutuhkan biaya yang sama, maka konsumen akan memilih barang yang memberi manfaat lebih besar.

3) Tidak selamanya konsumen dapat memperkirakan manfaat dengan tepat. Saat membeli suatu barang, bisa jadi manfaat yang diperoleh tidak sesuai dengan harga yang harus dibayarkan: Segelas kopi Starbuck, misalnya, ternyata lebih pahit untuk harga Rp.40.000,- per cangkir. Lebih nikmat kopi tubruk yang Rp.3.000,per gelasnya. Pengalaman tersebut akan menjadi informasi bagi konsumen yang akan memengaruhi keputusan konsumsinya mengenai kopi di masa yang akan datang.

4) Setiap barang dapat disubstitusi dengan barang lain. Dengan demikian konsumen dapat memperoleh kepuasan dengan berbagai cara.

5) Konsumen tunduk kepada hukum berkurangnya tambahan dan kepuasan (thelaw of diminishing marginal utility). Semakin banyak jumlah barang dikonsumsi, semakin kecil tambahan kepuasan yang dihasilkan. Jika untuk setiap tambahan barang diperlukan biaya sebesar harga barang tersebut $(P)$, maka konsumen akan berhenti membeli barang tersebut manakala tambahan manfaat yang diperolehnya (MU) sama besar dengan tambahan biaya yang harus dikeluarkan. Maka jumlah konsumsi yang dioptimalkan adalah dimana $\mathrm{MU}=\mathrm{P} .{ }^{20}$

20 Ibid., 


\subsection{Proses Pengambilan Keputusan pembelian}

Proses pengambilan yang sepesifik terdiri dari urutan kejadian berikut: pengenalan masalah, pencarian informasi, evaluasi alternatif, keputusan pembelian dan perilaku pascapembelian. Kotler mengemukakan pengertian keputusan pembelian yaitu :

"Keputusan pembelian adalah tindakan dari konsumen untuk mau membeli atau tidak terhadap suatu produk." 21

Tahap-tahap pengambilan keputusan menurut Kotler dan Keller dibagi ke dalam lima tahapan: ${ }^{22}$

a. Pengenalan Masalah

Proses membeli diawali saat pembeli menyadari adanya masalah kebutuhan. Pembeli menyadari adanya perbedaan antara kondisi yang sesungguhnya dan kondisi yang diinginkannya. Kebutuhan ini dapat disebabkan oleh rangsangan internal maupun internal dalam kasus pertama dari kebutuhan normal seseorang, yaitu rasa lapar, dahaga, atau seks meningkat sampai tingkat tertentu dan berubah menjadi dorongan. Atau suatu kebutuhan dapat timbul karena disebabkan eksternal seseorang yang melewati sebuah toko roti dan melihat roti yang baru selesai dibakar dapat merangsang rasa laparnya.

b. Pencarian Informasi

Seseorang konsumen yang mulai timbul minatnya akan terdorong untuk mencari informasi lebih banyak. Dalam hal ini dibedakan dalam dua tingkat, yaitu keadaan tingkat pencarian informasi yang sedang-sedang saja yang

\footnotetext{
${ }^{21}$ Kotler, Keller, Manajemen ,184.

22Ibid., 185.
}

disebut perhatian yang meningkat. Proses mencari informasi yang aktif dimana ia mencari bahan-bahan bacaan, menelpon teman-temannya, dan melakukan kegiatan untuk mempelajari yang lain. Sumber-sumber informasi konsumen dapat dibedakan menjadi empat kelompok yaitu: ${ }^{23}$

1) Sumber pribadi: keluarga, teman, tetangga, dan kenalan

2) Sumber komersial: iklan, tenaga penjualan, penyalur, kemasan, dan pameran.

3) Sumber umum: media massa dan organisasi konsumen.

4) Sumber pengalaman: pernah menangani, menguji, dan menggunaan produk.

Karena itu suatu perusahaan harus "menyusun strategi" agar merknya masuk ke perangkat pengenalan, perangkat pertimbangan, dan perangkat pilihan dari calon pembeli. Lebih jauh lagi, perusahaan harus mengidentifikasi merek lain yang ada diperangkat pilihan dari konsumen sehingga perusahaan dapat merencanakan daya tarik produknya yang bersaing.

c. Evaluasi Alternatif

Ada beberapa proses evaluasi keputusan. Kebanyakan model dari proses evaluasi konsumen sekarang yang bersifat kognitif, yaitu mereka memandang konsumen sebagai pembentuk penilaian terhadap produk terutama berdasarkan pada pertimbangan yang sadar dan rasional. ${ }^{24}$ Pada tahap ini konsumen dihadapkan pada beberapa pilihan produk yang akan dibelinya. Untuk itu konsumen melakukan evaluasi terhadap

\footnotetext{
23J. Setiadi, Perilaku., 16.

24 Kotler, Keller, Manajemen ,186
}

e-ISSN: $2686-6633$ 
barang mana yang benar-benar paling cocok untuk dibeli sesuai dengan kebutuhan dan keinginannya.

d. Keputusan Membeli

Pada tahap evaluasi, konsumen membentuk pereferensi terhadap merek-merek yang terdapat pada perangkat pilihan. Konsumen mungkin juga membentuk tujuan membeli untuk merek yang paling disukai. Walau demikian, dua faktor dapat mempengaruhi tujuan membeli dan keputusan membeli. Faktor pertama adalah sikap orang lain, sejauh mana sikap orang lain akan mempengaruhi alternatife pilihan seorang akan tergantung pada dua hal: (1) interaksi sikap negatif orang lain tersebut terhadap alternatif pilihan konsumen, dan (2) motivasi konsumen untuk menuruti keinginan orang lain tersebut. Semakin tinggi intensitas sikap orang lain tersebut akan semakin dekat hubungan orang tersebut dengan konsumen, maka semakin besar kemungkinan konsumen akan menyesuaikan tujuan pembeliannya. Tujuan pembelian juga akan dipengaruhi oleh faktor-faktor keadaan yang tidak terduga. Konsumen membentuk tujuan pembelian berdasarkan faktor-faktor seperti: pendapatan keluarga yang diharapkan, harga yang diharapkan, dan manfaat produk yang diharapkan. Pada saat konsumen akan bertindak, faktor-faktor keadaan yang tidak terduga mungkin timbul dan mengubah tujuan membeli. ${ }^{25}$

e. Perilaku sesudah pembelian

Sesudah pembelian terhadap suatu produk yang dilakukan konsumen akan melakukan beberapa tingkat kepuasan

25 Ibid., atau ketidakpuasan. Konsumen tersebut juga kana terlibat dalam tindakan sesudah pembelian dan penggunaan produk yang akan menarik minat pasar. Pekerjaan pemasar tidak akan berakhir pada saat suatu produk dibeli, tetapi akan terus berlangsung hingga periode sesudah pembelian.

Setelah pembelian suatu produk, seorang konsumen mungkin mendeteksi adanya suatu cacat. Beberapa pembeli tidak akan menginginkan produk cacat tersebut, yang lainnya akan bersifat netral dan beberapa bahkan mungkin melihat cacat itu sesuatu yang meningkatkan nilai produk.

Kepuasan atau ketidakpuasan konsumen pada suatu produk akan mempengaruhi tingkah laku berikutnya. Jika konsumen merasa puas, maka ia akan memperlihatkan kemungkinan yang lebih tinggi untuk membeli produk itu lagi. Konsumen yang tidak puas tersebut akan berusaha mengurangi ketidakpuasannya, karena ada kodrat manusia "untuk menciptakan keserasian, konsisten, dan keselarasan di antara pendapat, pengetahuan dan nilainilai di dalam dirinya." Konsumen yang tidak puas akan mengambil satu atau dua tindakan. Mereka mungkin akan mengurangi ketidakcocokannya dengan meninggalkan atau mengembalikan produk tersebut, atau mungkin mereka berusaha

ketidakcocokannya dengan mencari informasi yang mungkin mengkonfirmasikan ketidakcocokan produk tersebut sebagai bernilai tinggi (atau menghindari informasi yang mengkonfirmasikan produk tersebut sebagai bernilai rendah). ${ }^{26}$

${ }^{26}$ Ibid., 187. 


\section{Metode Penelitian}

Pendekatan yang digunakan dalam penelitian ini adalah pendekatan kuantitaif, karena penelitian ini terfokus untuk mengetahui pengaruh variabel kualitas produk dan desain terhadap keputusan pembelian Motor Yamaha Vixion. Sampel pada penelitian ini adalah sebagian dari beberapa anggota organisasi Motor Yamaha Vixion yang berjumlah 74 orang. Peneliti memberikan questioner kepada respondent tersebut. Quesioner menggunakan lima skala likert .

Teknik analisis data yang digunakan dalam penelitian ini adalah analisis kuantitaif, yaitu proses analisis terhadap data-data yang berbentuk angka dengan cara perhitungan secara statistik untuk mengukur kualitas produk dan desain terhadap keputusan pembelian motor. Analisa data dilakukan melalui tahap uni validitas, reabilitas, uji regresi berganda, dan uji asumsi klasik. Untuk pembuktian hipotesis penulis menggunakan uji $\mathrm{f}$ dan uji t. ${ }^{27}$

\section{Hasil Dan Pembahasan}

\subsection{Deskripsi Kuesioner dan Sampel}

\section{Penelitian}

Penelitian ini dilakukan pada Organisasi Vixion di Kota Palu yang beralamat di Kota Palu, Provinsi Sulawesi Tengah. Data penelitian menggunakan instrumen kuesioner yang dibagikan kepada anggota organisasi yang terdiri dari delapan

${ }^{27}$ Nurdin, N., \& Mir'atun, M. a. (2018).

Do Government And Private Sharia Commercial Banks Practice Similar Financial Social Responsibility Disclosure. Hunafa: Jurnal Studia Islamika, 15(2), 285-321.
Organisasi Motor Vixion, sebagai sampel penelitian.

Kuesioner disebarkan oleh peneliti kepada sampel yang diteliti dengan perincian sebagai berikut:

\begin{tabular}{|c|c|c|c|c|}
\hline & \multicolumn{4}{|c|}{$\begin{array}{c}\text { Tabel 1| } \\
\text { Deskripsi Kuesionet }\end{array}$} \\
\hline $\begin{array}{l}\text { Jumlah } \\
\text { Sampel }\end{array}$ & $\begin{array}{c}\text { Kuesiober } \\
\text { Disebar }\end{array}$ & $\begin{array}{c}\text { Kuesioter } \\
\text { Kenbali }\end{array}$ & $\begin{array}{c}\text { Kuesioner } \\
\text { Diolah }\end{array}$ & Presentase \\
\hline 74 & 74 & 74 & 74 & $100 \%$ \\
\hline
\end{tabular}

Dalam tabel 1 dijelaskan bahwa jumlah sampel yang digunakan dalam penelitian ini adalah 74 orang anggota organisasi. Adapun data responden dalam penelitian ini dapat dijelaskan dalam tabel sebagai berikut:

\section{Tabel 2}

Karakteristik Responden

\begin{tabular}{|c|c|c|c|}
\hline No & $\begin{array}{c}\text { Jenis } \\
\text { Kelamin }\end{array}$ & Jumlah & Presentase \\
\hline 1 & Laki-laki & 74 & $100 \%$ \\
\hline 2 & Perempuan & 0 & $0 \%$ \\
\hline \multicolumn{2}{|c|}{ Jumlah } & 74 & $100 \%$ \\
\hline
\end{tabular}

Pada tabel 2 menunjukkan bahwa dari 74 orang jumlah sampel dalam penelitian ini yang berjenis kelamin lakilaki berjumlah 74 orang (100\%). Hal ini menunjukan bahwa sampel dalam penelitian ini semua berjenis kelamin laki-laki.

\subsection{Uji Validitas dan Reliabilitas}

Untuk menggunakan instrument yang valid dan realibel dalam pengumpulan data, maka diharapkan hasil penelitian akan menjadi valid dan realibel.

Instrument yang dinyatakan valid dan realibel adalah: instrument yang 
valid, berarti alat ukur yang digunakan untuk mendapatkan data (mengukur) itu valid. Sedangkan instrumen yang realibel berarti bila digunakan untuk mengukur berkali-kali akan menghasilkan data yang sama.

a. Uji Validitas

Menurut Sugioyono dalam Sakinah, apabila validitas setiap jawaban yang diperoleh ketika memberikan daftar pertanyaan lebih besar dari 0,3 maka pertanyaan dianggap sudah valid. $^{28}$

Untuk mengetahui apaka butir pertanyaan yang valid atau tidak dapat dilihat pada tabel Item Total Statistics, kemudian lihat pada kolom Corrected Item-Total Corelation.

Tabel 3

Hasil Uji Validitas Instrumen

\begin{tabular}{|c|c|c|c|c|}
\hline Variabel & $\begin{array}{c}\text { Item } \\
\text { Pernyataun }\end{array}$ & $\begin{array}{l}\text { Corrected } \\
\text { Ttem total } \\
\text { Correinfion }\end{array}$ & $\begin{array}{c}\mathrm{R} \\
\text { Kritis }\end{array}$ & Ket. \\
\hline $\begin{array}{c}\text { Kulitas } \\
\text { Produk } \\
\text { (X1) }\end{array}$ & $\begin{array}{l}1 \\
2 \\
3 \\
4 \\
5 \\
6 \\
7\end{array}$ & $\begin{array}{l}0,313 \\
0,353 \\
0,456 \\
0,303 \\
0,418 \\
0,518 \\
0,584\end{array}$ & $\begin{array}{l}0,30 \\
0,30 \\
0,30 \\
0,30 \\
0,30 \\
0,30 \\
0,30\end{array}$ & $\begin{array}{l}\text { Valid } \\
\text { Valid } \\
\text { Valid } \\
\text { Valid } \\
\text { Valid } \\
\text { Valid } \\
\text { Valid }\end{array}$ \\
\hline $\begin{array}{c}\text { Desain } \\
\text { (X2) }\end{array}$ & $\begin{array}{l}1 \\
2 \\
3 \\
4 \\
5\end{array}$ & $\begin{array}{l}0,435 \\
0,385 \\
0,357 \\
0,368 \\
0,325\end{array}$ & $\begin{array}{l}0,30 \\
0,30 \\
0,30 \\
0,30 \\
0,30\end{array}$ & $\begin{array}{l}\text { Valid } \\
\text { Valid } \\
\text { Valid } \\
\text { Valid } \\
\text { Valid }\end{array}$ \\
\hline $\begin{array}{c}\text { Keputusan } \\
\text { Pembelian } \\
\text { (Y) }\end{array}$ & $\begin{array}{l}1 \\
2 \\
3 \\
4\end{array}$ & $\begin{array}{l}0,326 \\
0,397 \\
0,458 \\
0,503\end{array}$ & $\begin{array}{l}0,30 \\
0,30 \\
0,30 \\
0,30\end{array}$ & $\begin{array}{l}\text { Valid } \\
\text { Valid } \\
\text { Valid } \\
\text { Valid }\end{array}$ \\
\hline
\end{tabular}

Tabel 3 di atas, terlihat bahwa nilai rhitung pada kolom Corrected Item Total Correlation untuk masing-masing dari ke 3 variabel di atas dinyatakan semua pernyataan valid karena $r_{\text {hitung }}$ lebih besar dan positif dari 0,30.

b. Uji Reliabilitas

28Sakinah, Pengaruh Bauran Pemasaran Keputusan Membeli Kartu Prabayar Produk Telkomsel Pada Mahasiswa IAIN Palu, Skripsi, (Palu: IAIN 2014), 5.
Melakukan pengujian reliabilitas dalam penelitian ini digunakan program SPSS (Statistical Packaged For Sosial Siences) versi 21 dimana dalam mengukur reliabilitas disini menggunakan uji statistik Cronbach's Alpha (a). Suatu instrumen dinyatakan reliabel jika memiliki Cronbach's Alpha (a) lebih dari 0,60.

Hasil pengujian reliabilitas instrumen menggunakan alat bantu oleh statistik SPSS versi 21 for windows dapat diketahui sebagaimana tabel berikut.

Tabel 4

Hasil Uji Reliabilitas Instrumen

\begin{tabular}{|c|c|c|c|}
\hline Variabel & $\begin{array}{c}\text { Reliability } \\
\text { Caefficiert5 }\end{array}$ & $\begin{array}{c}\text { Cronbach } \\
\text { Alpha }\end{array}$ & Keterangan \\
\hline $\begin{array}{c}\text { Kualitas Produk } \\
(\mathrm{X} 1)\end{array}$ & 7 Item & 0,711 & Reliabel \\
\hline Desain (X2) & 5 Item & 0,619 & Reliabel \\
\hline $\begin{array}{c}\text { Keputusan } \\
\text { Pembelian (Y) }\end{array}$ & 4 Item & 0,635 & Reliabel \\
\hline
\end{tabular}

Tabel 4 di atas dapat diketahui bahwa masing-masing variabel memiliki Cronbach's Alpha (a) lebih dari 0,60 (a > $0,60)$, yang artinya bahwa semua variabel yaitu X1, X2, dan Y adalah reliabel. Dengan demikian pengolahan data dapat dilanjutkan ke jenjang selanjutnya.

\subsection{Analisis Regresi Linear Berganda}

Analisis regresi linear berganda adalah salah satu alat statistik non parametrik yang berfungsi menganalisis keterkaitan dan keterhubungan di antara dua atau lebih variabel penelitian yang berbeda, yaitu variabel dependen dan independen. Selanjutnya dari hasil analisis regresi berganda ini akan diketahui ada tidaknya pengaruh secara parsial dan serempak variabel kualitas produk (X1), desain (X2), terhadap keputusan pembelian $(\mathrm{Y})$. 
Berdasarkan hasil olah data menggunakan SPSS 21 for Windows diperoleh hasil analisis regresi berganda sebagai berikut.

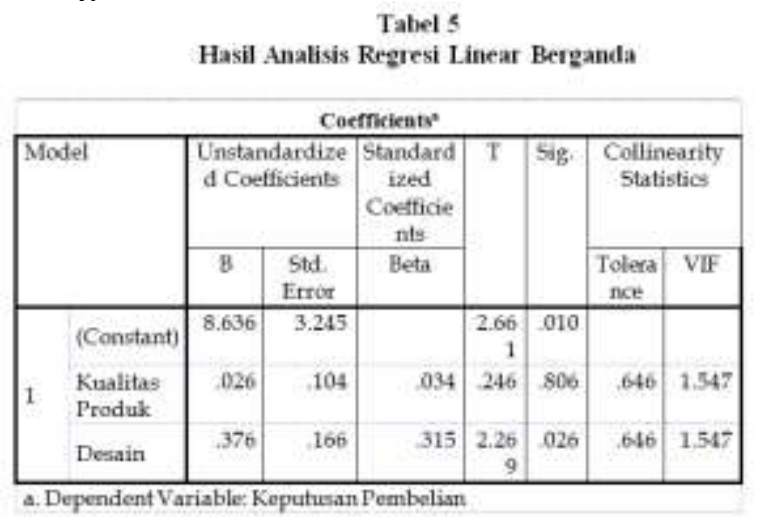

Hasil analisis regresi linear berganda pada tabel 5 di atas, kemudian dimasukkan ke dalam model persamaan regresi berganda sebagai berikut:

$$
\mathrm{Y}=8.636+0,026 \times 1+
$$

$0,376 \times 2+0,01 e i$

Persamaan regresi linear berganda di atas menunjukkan bahwa kedua variabel independen ( Kualitas Produk dan Desain) memiliki arah yang positif terhadap variabel dependen (keputusan membeli). Hasil perhitungan di atas dapat dijelaskan sebagai berikut:

a) Konstanta positif sebesar 8.636 mempunyai arti keputusan pembelian anggota organisasi akan meningkat sebesar 8.636 jika variabel kualitas produk, dan desain, konstan atau bernilai nol (0).

b) Koefisien regresi Kualitas Produk (X1) sebesar 0,026 bernilai positif. Nilai positif $(+)$ pada variabel kualitas produk mempunyai makna searah, artinya bahwa setiap terjadinya peningkatan satu satuan variable produk (X1) akan meningkatkan keputusan pembelian sebesar 0,026jika variabel lain dianggap konstan.
Koefisien regresi Desain (X2) sebesar 0,376 bernilai positif. Nilai positif $(+)$ pada variabel Desain mempunyai makna searah, artinya bahwa setiap terjadinya peningkatan satu satuan variabel Desain (X2) akan meningkatkan keputusan pembelian sebesar 0,376 jika variabel lain dianggap konstan.

\subsection{Hasil Pengujian Hipotesis}

a. Uji F (Uji Serempak)

Pengujian ini digunakan untuk mengetahui ingin diketahui apakah variabel independen $(X)$ berpengaruh secara bersama-sama memberikan kontribusi secara signifikan terhadap variabel dependen.

Tabel 6

Hasil Uji F (Uji Serempak)

\begin{tabular}{|c|c|c|c|c|c|c|}
\hline \multicolumn{7}{|c|}{ ANOVA } \\
\hline \multicolumn{2}{|c|}{ Model } & Sum of & Df & Mean & $\mathrm{F}$ & Sig. \\
\hline \multirow{3}{*}{1} & Regression & 28.444 & 2 & 14.222 & 4.544 & $.014^{b}$ \\
\hline & Residual & 222.204 & 71 & 3.130 & & \\
\hline & Total & 250.649 & 73 & & & \\
\hline
\end{tabular}

a. Dependent Variable: Keputusan Pembelian

b. Predictors: (Constant), Desain, Kualitas Produk

Berdasarkan hasil uji Anova (Analisis Of Varians), atau $\mathrm{F}$ tes diperoleh nilai $F_{\text {hitung sebesar } 4,544>F_{\text {tabel }} 3,125}$ dengan nilai Sig sebesar 0,014 lebih kecil dibandingkan alpha 0,05. Dengan demikian hasil ini memberikan makna bahwa variabel Kualitas Produk (X1), Desain (X2), secara serempak berpengaruh signifikan terhadap Keputusan Pembelian (Y).

\section{b. Uji T (Uji Parsial)}

Uji parsial digunakan untuk menguji apakah variabel independen benar-benar memberikan kontribusi terhadap variabel dependen. Berikut di bawah ini tabel hasil uji $\mathrm{T}$ pada tabel coeficients. 


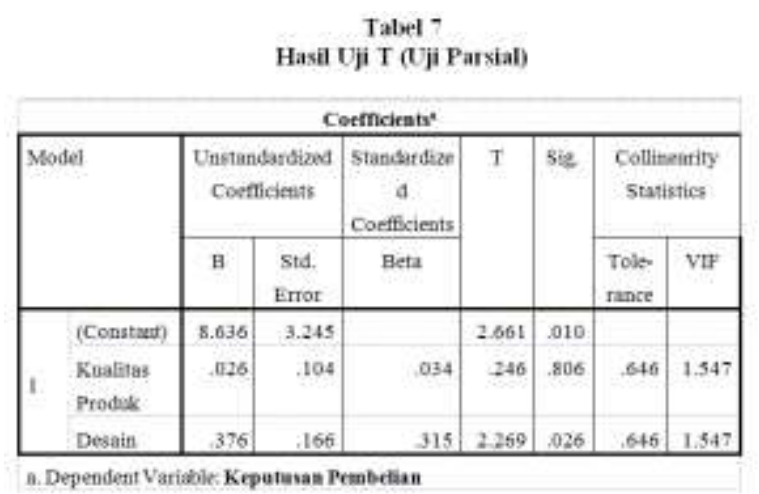

Berdasarkan hasil perhitungan statistik uji T dari 2 variabel independen yang dimasukkan dalam model regresi terlihat bahwa kualitas produk (X1) diperoleh nilai $t_{\text {hitung }} 0,246<t_{\text {tabel }} 1.993$ dan memilki nilai signifikan (sig) 0,80 pada tabel coefficients dengan nilai a (tingkat siginfikan) 0,05. Artinya 0,80 > 0,05 . Dengan nilai ini memberikan makna bahwa secara parsial variable Kualitas Produk (X1) tidak memberikan pengaruh secara siginfikan terhadap Keputusan Pembelian (Y). Adapun besaran pengaruhnya dapat dilihat pada kolom Beta. Besaran pengaruh variabel $\mathrm{X} 1$ terhadap variabel $\mathrm{Y}$ yaitu 3.4\%.

Sedangkan desain (X2) diperoleh nilai $t$ hitung $2.269>t_{\text {tabel }} 1,993$ dan nilai signifikan (sig) 0,02 lebih kecil dari nilai a 0,05 . Artinya $0,02<0,05$. Dengan nilai ini memberikan makna bahwa variabel Desain (X2) memberikan pengaruh signifikan terhadap keputusan pembelian (Y). Adapun besaran pengaruhnya dapat dilihat pada kolom Beta. Besaran pengaruh variabel X2 terhadap variabel $Y$ yaitu $31,5 \%$. Jadi, dari beberapa variabel $X$ yang diteliti. Maka, variabel yang paling besar pengaruhnya terhadap keputusan pembelian Motor Yamaha Vixion adalah variabel Desain dengan besaran pengaruh yaitu $31,5 \%$.

\subsection{Koefisien Determinasi}

Analisis koefisien determinasi dilakukan untuk mengetahui seberapa besar persentase kontribusi independen $(\mathrm{X})$ terhadap variabel dependen $(\mathrm{Y})$. Dari hasil perhitungan melalui alat ukur statistik SPSS 21 For Windows didapatkan nilai koefisien determinasi sebagai berikut.

\begin{tabular}{|c|c|c|c|c|}
\hline \multicolumn{5}{|c|}{ Model Summary ${ }^{b}$} \\
\hline Model & $\mathrm{R}$ & $\begin{array}{c}\mathrm{R} \\
\text { Square } \\
\end{array}$ & $\begin{array}{c}\text { Adjusted R } \\
\text { Square } \\
\end{array}$ & $\begin{array}{l}\text { Std. Error of } \\
\text { the Estimate }\end{array}$ \\
\hline 1 & $.337^{3}$ & .113 & .089 & 1.76908 \\
\hline
\end{tabular}

\section{b. Dependent Variable: KEPUTUSANPEMBELIAN}

Tampilan output SPSS Model Summary besarnya $\mathrm{R}^{2}$ adalah 11,3 hal ini berarti bahwa variasi perubahan variabel keputusan pembelian (Y) dipengaruhi oleh perubahan variabel independen yang terdiri dari Kualitas Produk (X1), Desain (X2), Sebesar 11,3\%. Sedangkan sisanya $(100 \%-11,3 \%=$ $88,7 \%$ ) jadi, $88,7 \%$ dipengaruhi oleh faktor lain yang tidak diteliti di luar dari penelitian ini.

\subsection{Pembahasan}

Hasil pengujian dengan menggunakan analisis regresi berganda dengan bantuan SPSS 21 for Windows, menunjukkan bahwa secara serempak variabel $\mathrm{X} 1$ dan $\mathrm{X} 2$ memiliki pengaruh positif terhadap keputusan pembelian anggota Organisasi Yamaha Vixion. Begitu pula dengan pengaruh masingmasing variabel secara parsial masingmasing memiliki pengaruh dengan besaran pengaruh yang berbeda.

Berdasarkan hasil uji Anova (Analisis Of Varians), atau $\mathrm{F}$ tes diperoleh 
nilai $F_{\text {hitung }}$ sebesar $4,544>F_{\text {tabel }} 3,125$ dengan nilai Sig sebesar 0,014 lebih kecil dibandingkan alpha 0,05. Dengan demikian hasil ini memberikan makna bahwa variable Kualitas Produk (X1), berpengaruh tetapi tidak signifikan Desain (X2), berpengaruh signifikan terhadap Keputusan Pembelian (Y).

Kualitas Produk (X1) diperoleh nila thitung $0,246<t_{\text {tabel }} 1.993$ dan memilki nilai signifikan (sig) 0,80 pada tabel coefficients dengan nilai a (tingkat siginfikan) 0,05. Artinya 0,80 $>0,05$. Dengan nilai ini memberikan makna bahwa secara parsial variable Kualitas produk Produk (X1) memberikan pengaruh positif namun tidak berpengaruh secara signifikan terhadap keputusan pembelian (Y). Adapun besaran pengaruhnya dapat dilihat pada kolom Beta. Besaran pengaruh variabel $\mathrm{X} 1$ terhadap variabel $\mathrm{Y}$ yaitu 3.4\%.

Hasil penelitian tidak sejalan dengan penelitian yang dilakukan oleh Tina Martini, yang menunjukkan bahwa variabel kualitas produk berpengaruh negatif terhadap keputusan pembelian kendaraan bermotor merek honda jenis skutermetik.

Kualitas produk menjadi faktor yang mempengaruhi pembelian konsumen. Dalam Islam, kualitas produk adalah produk yang berdaya guna yang menghasilkan material, moral, spiritual bagi konsumen. Suatu yang tidak berdaya guna dilarang dalam Islam bukan merupakan produk dalam pengertian Islam. Tetapi dalam Islam barang yang dipertukarkan dan berdaya guna secara moral. ${ }^{29}$

${ }^{29}$ Veitzal Rivai Zainal, Muhammad Syafei Antoniu, Muliaman Darmansyah Hadad, Islamic Busness Management : Praktik Menejemen Bisnis
Desain (X2) diperoleh nilai $t$ hitung $2.269>t_{\text {tabel }} 1,993$ dan nilai signifikan (sig) 0,02 lebih kecil dari nilai a 0,05. Artinya $0,02<0,05$. Dengan nilai ini memberikan makna bahwa variabel Desain (X2) memberikan pengaruh signifikan terhadap keputusan pembelian (Y). Adapun besaran pengaruhnya dapat dilihat pada kolom Beta. Besaran pengaruh variabel X2 terhadap variabel $Y$ yaitu 31,5\% .

Sesuai dengan hasil jawaban responden yang ada bahwa, 53 responden atau $71,6 \%$ yang samgat setuju dengan pernyataan bahwa motor Yamaha Vixion mudah dan nyaman saat dikendarai dan juga terdapat 55 responden atau $74,3 \%$ yang sangat setuju dengan pernyataan bahwa Motor Yamaha Vixion memiliki Striping Body yang mempergagah penampilan. Hal dianggap telah menjadi pendorong konsumen untuk melakukan keputusan pembelian terhadap Motor Yamaha Vixion.

Berdasarkan hasil analisis dari jawaban responden tersebut, sudah seharusnya desain menjadi salah satu alasan mereka untuk melakukan keputusan pembelian terhadap motor Yamaha Vixion, karena desain yang ditawarkan telah sesuai dengan yang mereka harapkan. Jika PT Yamaha Indonesia lebih meningkatkan desain dari berbagai produk yang ditawarkan, maka akan dapat meningkatkan keputusan pembelian terhadap produk motor tersebut.

Penelitian ini menunjukkan bahwa konsumen pada dasarnya suka dan tertarik dengan tampilan yang

Yang Sesuai Syariat Islam (Yogyakarta: BPFE, 2014), 380.

e-ISSN: $2686-6633$ 
menarik dipandang matanya apa bila sudah ada ketertarikan maka akan ada rasa ingin memiliki, tampilan menarik yang dimaksud disini adalah desain dari suatu produk itu sendiri pada masa sekarang. Hasil penelitian sejalan dengan penelitian yang dilakukan oleh Agustin Dwi Carissa (2015), yang menunjukkan bahwa variabel Desain berpengaruh positif terhadap keputusan pembelian pada Motor Yamaha Vega.

\section{Kesimpulan}

Berdasarkan hasil penelitian pada bab IV dapat disimpulkan bahwa ecara parsial variabel kualitas Produk (X1) memberikan pengaruh positif namun tidak berpengaruh secara signifikan terhadap keputusan pembelian (Y). Adapun besaran pengaruhnya dapat dilihat pada kolom Beta. Besaran pengaruh variabel $\mathrm{X} 1$ terhadap variabel $\mathrm{Y}$ yaitu $3.4 \%$. Secara pasial variabel desain (X2) memberikan pengaruh signifikan terhadap keputusan pembelian (Y). Adapun besaran pengaruhnya dapat dilihat pada kolom Beta. Besaran pengaruh variabel $\mathrm{X} 2$ terhadap variabel $Y$ yaitu 31,5\%

\section{Daftar Pustaka}

A.R. Anggitan Rizana Analisis Pengaruh Kualitas Produk, Harga,dan Promosi terhadap |loyalitas Pelanggan dengan Minat Beli Ulang Sebagai Variabel Intervening" jurnal kudus, stain kudus, 2013. http:/ / eprints.dinus.ac.id diakses 14 januari 2019.

Abdul Karim Amirullah. Malik Abdul, Tafsir Al-Azhar, Surabaya: Yayasan Litimojong, 1981
Abdullah. Thamrin dan Francis Tantri, Manajemen Pemasaran, Jakarta: Rajawali Pers, 2013

Adrian. Pendiri Vixion Jari-Jari Palu Tahun 2016, "Wawancara", Palu 21 April 2019

Ahyani. Agus, Perencanaan Sistem Produksi , Yogyakarta, BPFE, : 1985.

Anchu. Ketua Vixion Ruji Squad Palu Tahun 2019, "Wawancara”, Palu, 22 April 2019.

Anwar. Ketua Yamaha vixion club indonesia tahun 2019, “wawancara", palu 27 April 2019.

Bangka. Mio dan Vixion raih Indonesia Best Brend Award, diakses melalui http://tribunnews.com, diakses 10 Januari 2018.

Carrisa. Agustin Dwi "Pengaruh desain produk dan promosi penjualan terhadap keputusan pembelian pada sepeda motor Yamaha vega ",.jurnal (Surabaya: universitas negeri Surabaya. 2015

Enas, Adnun Rusyana, Cara mudah belajar SPSS 17.0 dan Aplikasi Statistik Penelitian, Cet.III; Bandung ALFABETA, 2013.

Endding, Ketua Vixion Young Riders Commonity Tahun 2019, "Wawancara", Palu 22 April 2019.

Evan. Pendiri Celebes Vixion Club Tahun 2016, "Wawancara”, Palu 22 April 2019.

Ferdinand. Rio, Ketua Forum Bikers Bersatu Sulawesi Tengah, wawancara tanggal 8 Januari 2019 di Sekret Forum.

Gitosudamo. Indriyo. Manajemen Pemasaran, Yogyakarta : BPFE, 2000.

Gozali. Imam, Aplikasi Analisis Multivariate dengan Program IBM 
SPSS 21, Edisi ketujuh .Semarang: Badan Penerbit Universitas Diponegoro, 2013.

Gunawan.Indra, selaku Jendral Marketing, wawancara tanggal 14 Februari 2019 di CV Akai Jaya Central.

Idem. SPSS Untuk Penelitian Yogyakarta: Pustaka Baru Press, 2015

Indrawan. Rully dan Popy Yaniawati, Metode Penelitian, Cet.I; Bandung: PT. Rafika Aditama, 2014.

Iskandar. Yogi, Pengaruh Kesesuaian Kompensasi terhadap Kinerja Karyawan pada PT. Bentoel Distribusi Utama Cabang Palu, Skripsi

Kementerian Agama Repuplik indonesia, Al-Qur'an dan Terjemahan, Depot: Yakfi, 2015.

Khairunnisa. Ita,. Pengaruh Bauran Pemasaran Jasa Terhadap Keputusan Mahasiswa dalam Memilih Perguruan Tinggi IAIN Palu, Skripsi Fakultas Ekonomi 2017.

Kompas. Yamaha Raih 6 Penghargaan Otomotif Award 2014, https://olahraga.kompas.com diakses 10 Januari 2018.

Kotler. Philip dan Gary Amstrong, Prinsip-Prinsip Manajemen, Jakarta : Erlangga : 2006.

Kotler. Phlip dan Kevin Lane Keller, Manajemen Pemasaran, Cet. XIII; Jakarta: Erlangga, 2009.

Lamarton. Yohanes Konsultan Manajemen, Jakarta, Erlangga, : 1984.

Lupiyado. Rambat dan A. Hamdani, Manajemen Pemasaran Jasa. Jakarta, Salemba Empat : 2009.

Martin. Tina "Analisis Pengaruh harga, kualitas produk dan desain terhadap pembelian kendaraan bermotor merk honda skutermetic", skripsi Kudus, STAIN Kudus, 2015, http://www , Tina Martani-2015-academia.edu diakses 11 Januari 2019.

Marvel. Pendiri Riders Vixion Independen Tahun 2017, "Wawancara", Palu 21 April 2019. Nasution. Mustafa Edwin, Pengenalan Eksklusif Ekonomi Islam, Jakarta : Kencana ,2007.

Nurdin, N. (2016). The Roles of Information Technology in Islamic Bank Knowledge Management: A study of Two Syariah Banks in Palu. Hunafa: Jurnal Studia Islamika, 13(2), 181217.

https:/ /doi.org/https:/ / doi.org/ 10.24239/jsi.v13i2.444.181-217

Nurdin, N., \& Mir'atun, M. a. (2018). Do Government And Private Sharia Commercial Banks Practice Similar Financial Social Responsibility Disclosure. Hunafa: Jurnal Studia Islamika, 15(2), 285321.

Pertamax. Yamaha Vixion dinobatkan jadi The Best Seller Sport dalam Motorplus, https:/ / pertamax7.com, diakses 10 Januari 2018.

Pradityo. Tutu Yamaha Vixion subet Best Brend Award 2017 https://m.otosia.com, diakses 10 januari 2018.

Prawirosentono. Suyadi, Filosofi Baru Tentang Manajemen Mutu Terpadu Total Quality Management Abad 21 Studi Kasus dan Analisis, Jakarta, Bumi Aksara, : 2002.

Priyatno. Dwi, Analisis Korelasi, Regresi dan Multivariate dengan SPSS Cet. I, Yogyakarta: GAVA MEDIA, 2013 
Purwanto. Asih " pengaruh kualitas Produk, Promosi, dan Desain Terhadap Keputusan Pembelian Kendaraan Bermotor Yamaha Mio" Skripsi (surakarta: Universitas Muhammadiyah Surakarta, 2008 hppt://eprints. ums.ac. id Diakses, 10 januari 2019.

Rahmawati. Siti, "Pengaruh Tren Fashion terhadap Keputusan Membeli Busana Muslim dikalangan Mahasiswa IAIN Palu". Skripsi tidak diterbitkan Palu Jurusan Ekonomi Islam Fakultas Syariah dan Ekonomi Islam IAIN Palu, 2017

Riduan. Penelitian untuk Guru, Karyawan dan Peneliti Pemula, Bandung: ALFABETA, 2012

S. Etta Mamang dan Sopiah, Perilaku Konsumen, Yogyakarta : Andi : 2014.

Sakinah, Pengaruh Bauran Pemasaran Keputusan Membeli Kartu Prabayar Produk Telkomsel Pada Mahasiswa IAIN Palu, Skripsi, Palu: IAIN 2014

Sarjono, Haryadi dan Winda Julianti, SPSS vs Lisrel Sebuah Penngantar, Aplikasi Untuk Riset, Jakarta: Salemba Empat, 2011

Setiadi. Nugoroho J. Perilaku Konsumen, Ed. Ref, Jakarta: Kencana Prenada Grup, 2010.

Siregar, Sofyan, Statistika Deskriptif untuk Penelitian Dilengkapi Perhitungan Manual dan Aplikasi SPSS Versi 17, Ed.1, Cet. 5, Jakarta: Rajawali Pers, 2016 Metode Statistik Parametrik Penelitian Kuantitaif dilengkapi dengan perbandingan perhitungan manual dan SPSS, Jakarta: Bumi Aksara, 2013.

Stanton. Riset Pemasaran dan Perilaku Konsumen Jakarta : Gramedia Pustaka Utama dan Jakarta Busines Research Center, 2000.

Succeng. Riski, Ketua Generasi Vixion Club Indonesia Tahun 2019, "Wawancara", Palu, 27 April 2019.

Sugiyono. Metode Penelitian Administrasi, Bandung: ALFABETA, 2011.

Sugiyono. Metode Penelitian Kuantitatif Kualitatif dan RED. Bandung: Alfabeta, 2013

Sulaiman.Wahid, Analisis Regresi Mengg unakan SPSS: Contoh Kasus dan Pe mecahannya Yogyakarta: Andi, 2010.

Supardi. Metode Penelitian Ekonomi dan Bisnis, Yogyakarta, UII Perss, 2005.

Taniredja. Tukiran dan Hidayati Mustafidah, Penelitian Kuantitatif Sebuah Pengantar. Purwokerto, ALFABETA, 2011.

Tis. Fred Mahatma Pengghargaan Otomotif Award 2018, http://wartakota.com diakses 10 Januari 2018.

Wikipedia. Pengertian Yamaha Vixion, http://id.m.wikipedia.org/wiki/ya maha vixion, diakses 10 Januari 2018.

Zainal. Veitzal Rivai, Muhammad Syafei Antoniu, Muliaman Darmansyah Hadad, Islamic Busness Management : Praktik Menejemen Bisnis Yang Sesuai Syariat Islam Yogyakarta: BPFE, 2014 